\author{
Aïci \\ https://orcid.org/0000-0002-7584-6284 \\ кандидат мистеитвознавства, \\ викладач кафедри фортепіано консерваторії \\ Внутрішньої Монголіі \\ ayisiayisi141@gmail.com
}

\title{
СЕМАНТИЧНІ ВЛАСТИВОСТІ ФОРТЕПІАННОЇ КОНЦЕРТНОСТІ ЯК СТИЛЬОВОЇ ПАРАДИГМИ КОМПОЗИТОРСЬКОЇ І ВИКОНАВСЬКОЇ ТВОРЧОСТІ С. ПРОКОФ'СВА (на прикладі Другого фортепіанного конщерту)
}

\begin{abstract}
Мета роботи. У статті зроблений компаративний аналіз виконавських інтерпретацій Другого фортепіанного концерту С. Прокоф'єва китайської піаністки Ю. Ванг (на прізвисько «літаючі пальці», що можна порівняти з «чарівними літаючими пальцями» самого Прокоф'єва) $i$ деяких вітчизняних піаністів вищого ешелону. Виявляються стильові параметри і стилістичні прийоми, характерні для Концерту, які створюють психологічно складну систему взаємоперетворюваних образів, що індивідуально розуміються різними інтерпретаторами. Методологія дослідження полягає в застосуванні історичного, естетичного, жканрово-стильового, музикознавчого аналітичного і виконавського підходів. Важливим видався компаративний метод, використаний для виявлення подібності й відмінностей виконавських інтерпретацій. Наукова новизна визначається висуненням принципово оновленого аналітичного підходу до фортепіанних концертів С. Прокоф'єва, у тому числі з боку їх виконавської тембрально-звукової властивості. Уточнюється специфіка створення семантичної моделі фортепіанних концертів Прокоф'єва китайськими піаністами, з урахуванням естетичного та інтонаційно-мовного підходів. Висновки. Виявлені характеристики виконавських інтерпретацій Другого фортепіанного кониерту Прокоф’єва дозволяють визначити семантичні властивості фортепіанної концертності як стильової парадигми не лише композиторської, а й виконавської творчості, яка спроможна отримувати відчутний резонанс при взаємодії з установками національних піаністичних шкіл, віртуозно-актуалізованих специфічних темброво-артикуляційних властивостей фортепіанного звучання та естетичного концепту Радості.
\end{abstract}

Ключові слова: жанр інструментального концерту, фортепіанний концерт, семантичні властивості фортепіанної концертності, фортепіанне звучання, концепт Радості, виконавська інтерпретація. 
Ayisi, PhD of Art, Teacher of the Piano Department of the Conservatory of Music Conservatory of Inner Mongolia

Semantic properties of fortepian concertoness as a style paradigm of composite and performance creativity S. Prokofiev (on the example of the Second Piano Concert)

Objective. In the article, a comparative analysis of the performance interpretations of the Second Prokofiev Piano Concerto by the Chinese pianist Yu. Wang (nicknamed «flying fingers», which can be compared with Prokofiev's «magic flying fingers») and some Russian top-flight pianists. Stylistic parameters and stylistic devices characteristic for this concert are revealed, which create a psychologically complex system of mutually transforming images, individually understood by different interpreters. The methodology of the research consists in the application of historical, aesthetic, genre-style, musicological analytical and performing approaches. Important was the comparative method used to identify similarities and differences in performance interpretations. Scientific novelty is determined by the nomination of a fundamentally renewed analytical approach to Prokofiev's piano concertos, including on the part of their performing timbral and sound properties. The specifics of the creation of the semantic model of Prokofiev's piano concerts by Chinese pianists are specified, taking into account the aesthetic and intonational-speech approaches. Conclusions. The revealed characteristics of the performance interpretations of the Second Prokofiev Piano Concerto make it possible to determine the semantic properties of piano concertoness as a style paradigm of not only compositional but also performing art that is capable of receiving a tangible resonance when interacting with the settings of national pianistic schools, masterly actualized specific timbre-articulatory properties of piano sounding and aesthetic concept of Joy.

Keywords: genre of instrumental concert, piano concerto, semantic properties of piano concertoness, piano sound, concept of Joy, performance interpretation.

Айси, кандидат искусствоведения, преподаватель кафедры фортепиано консерватории Внутренней Монголии

Семантические свойства фортепианной концертности как стилевой парадигмы композиторского и исполнительского творчества С. Прокофьева (на примере Второго фортепианного концерта)

Цель работы. В статье осуществлен компаративный анализ исполнительских интерпретаций Второго фортепианного концерта Прокофьева китайской пианистки Ю. Ванг (по прозвищу «летающие пальиы», что можно сравнить с «волшебными летающими пальцами» самого Прокофьева) и некоторых отечественных пианистов высшего эшелона. Выявляются стилевые параметры и стилистические приемы, характерные для данного концерта, которые создают психологически сложную систему взаимопревращающихся образов, индивидуально понимаемых различными интерпретаторами. Методология исследования заключа- 
ется в применении исторического, эстетического, жканрово-стилевого, музыковедческого аналитического и исполнительского подходов. Важным оказался компаративный метод, использованный для выявления сходства и различий исполнительских интерпретаций. Научная новизна определяется выдвижением приниипиально обновленного аналитического подхода к фортепианным кониертам Прокофьева, в том числе со стороны их исполнительских тембрально-звуковых свойств. Уточняется специфика создания семантической модели фортепианных концертов Прокофьева китайскими пианистами, с учетом эстетического и интонационно-речевого подходов. Выводы. Выявленные характеристики исполнительских интерпретаций Второго фортепианного концерта Прокофьева позволяют определить семантические свойства фортепианной концертности как стилевой парадигмы не только композиторской, но и исполнительского творчества, которая способна получать ощутимый резонанс при взаимодействии с установками национальных пианистических школ, виртуозно-актуализированных специфических темброво-артикуляционных свойств фортепианного звучания и эстетического концепта Радости.

Ключевые слова: жсанр инструментального кониерта, фортепианный концерт, семантические свойства фортепианной концертности, фортепианное звучание, концепт Радости, исполнительская интерпретация.

Актуальність теми дослідження. Жанр концерту привертає увагу композиторів і виконавців (тим більше творців, що поєднують ці якості в одній особі, подібно С. Прокоф’єву) практично невичерпними можливостями втілення різних музично-драматургічних, стилістичних, інструментально-тембральних і віртуозних завдань. Особливо актуальними наприкінці XX - початку XXI століття стають інтерпретативні аспекти апробованих у виконавській практиці фортепіанних концертів, наприклад, С. Прокоф’єва, з урахуванням китайського виконавського буму зазначеного періоду, що становить актуальну сферу сучасних музикознавчих досліджень.

Огляд досліджень і публікацій з обраної тематики. Вивченню теоретичних основ інструментального концерту присвячені численні статті, монографії, дисертації. Однією з перших таких робіт слід вважати цикл статей Б. Асаф’єва у «Книзі про Стравінського» [1], де автор аналізує такі риси жанрової форми, як пластичність мотивів, роль зіставлення контрастних звучностей, значення імпровізаційних прийомів і т. д. Фундаментальні праці Л. Раабе, М. Друскіна, І. Кузнєцова, Г. Орлова, М. Тараканова, О. Долинської, І. Гребньової, Е. Самойленко та ін. пропонують ряд принципово нових положень про 
сутність жанру концерту в цілому. Творчість С. Прокоф’єва досліджується в дисертаційних роботах А. Калашнікової, Н. Кравець, О. Ляховича, монографіях Б. Асаф’єва, Л. Гаккеля, В. Дельсона, Е. Денісова, О. Долинської, І. Мартинова та ін. Процеси формування та розвитку китайської фортепіанної школи спеціально досліджує Сюй Бо [5], вказуючи на «знаковість» фортепіано і європейської класики для розвитку сучасної китайської культури, а також «інші» національно-стильові та етнопсихологічні підстави китайських піаністів з їх домінантно-естетичним підходом.

Метою статті є компаративний аналіз інтерпретацій Другого фортепіанного концерту С. Прокоф'єва з урахуванням взаємодії часових модусів теперішнього виконання і минулого досвіду музичної творчості - $з$ притаманними їм жанрово-стильовими константами.

Виклад основного матеріалу. С. Прокоф'єв включив до жанру сольного концерту надзвичайно різноманітні жанрові модифікації (що стали надалі еталоном для його розвитку в другій половині XX століття) і збагатив концертний жанр новими стильовими прийомами концертності. Щодо прокоф'євської концертності варто відзначити стабільність ігрового принципу композиторського та виконавського мислення в їх єдності. При цьому названі чесноти зовсім не виключають інших (в рамках одного твору), в тому числі тих, що здаються протилежними. «Концертність, театральність, гра, симфонізм не стають у Прокоф'єва взаємозаперечуваними категоріями - вони пов'язані одна з одною, що становить новизну його інструментального стилю» $[3,19]$. Н. Кравець схематично відображає дію різних закономірностей в концертах Прокоф'єва у вигляді системи кіл, що пересікаються, стверджуючи, що подібний взаємозв'язок відмінних, здавалося б, явищ виходить з самої специфіки феномену концертності. Додамо сюди внутрішній модус Радості, що виявляє цілісність світосприйняття і музичної логіки розвитку в єдності моторного-ліричного, як характерної риси прокоф'євської творчості і життя.

Природно постає питання озвучування подібних концептів іншими особистостями-виконавцями. Тут найважливішу роль (крім інструментальної технології, співзвучності особистісних прагнень) грає складне переплетення тимчасових модусів справжнього виконання, минулого досвіду музичної творчості з властивими їм жанрово-стильовими константами і спрямованість до майбутніх смислових інтенцій музичного твору (і епохальних смислових проекцій). Така полімодальність музичної темпоральності створює і особливі 
завдання музично-виконавської інтерпретації як складноопосередкованого змістовно-часового процесу. Тут власна виконавська мова (природно пов'язана з авторським композиторським та індивідуально-самостійний) спирається на ставлення до ритму і засобів агогіки, моделюючи провідні умови виконавської волі і виконавського порядку на всіх рівнях виконавчої форми (а це найважливіша частина прокоф'євського стилю).

Не менш важливого значення, на наш погляд, в інтерпретації прокоф'євських концертів набувають якісні інструментально-звукові параметри, здатність піаніста (і диригента, інструменталістів оркестру) не спрощувати (в даному випадку) розуміння прокоф’євського «удару», який не повинен перетворитися на «бій» 3 інструментом, а має, на основі високої техніко-технологічної майстерності фортепіанного звуковидобування і звуковедення, стати художнім засобом вираження Радості як концептуальної якості і радості звуку, сповненого виконавським тонусом, майже містичними діалогічними відносинами виконавця і його інструмента, прокоф'євської «молодіжно»-оптимістичної енергії пальцевого «уречевлення» кришталево-прозорого «єсіповського» туше. В цілому в нотному тексті немає нічого неважливого - кожен його елемент має семіотичне навантаження, що впорядковується свідомістю виконавця. Тому важливо контекстне ознайомлення з творчістю композитора в цілому, включаючи його особистісні інтенції, стилістичні традиції виконання його музики (по можливості різні, включаючи авторські).

Важливий ще той факт, що виконавець є продуктом певного соціального середовища та історичної епохи; національної та релігійної приналежності, виконавської школи і т. д., що породжує варіантну множинність виконавської інтерпретації. Тут необхідно зазначити актуалізацію зі специфічними властивостями китайського фортепіанного виконавства останніх десятиліть, провідні представники якого вже міцно утвердилися на світовому фортепіанному «ринку».

Китайський фортепіанний «бум» останніх десятиліть відображає загальну культурну позицію країни, де у вивченні культур розвинених країн саме фортепіано з його потенціалом найвищих технічних навичок стало для китайців однією з цілей в досягненні певного рівня цивілізації, «знаковими уміннями, які уособлюють... здатність до освоєння передових технологій... до європеїзації і культурної глобальної інтеграції» [5]. Тому основою репертуару китайських піаністів була і залишається європейська класика (в широкому розумінні), 
однак не вся. У жанрі концерту перевага віддається творам Моцарта, Шопена, Чайковського, Брамса, Рахманінова, Прокоф'єва (на афішах особливо часто зустрічаються імена останніх трьох композиторів). А ось концерти Бетховена - не часто, між тим як його сонати користуються великою популярністю. При цьому китайський піаністичний бум відбувається в країні, яка не має «серйозної фортепіанної історії» на тлі падіння інтересу до рояля у світі. А «інша» інтерпретація європейської музики китайцями формується на інших національно-стильових та етнопсихологічних підставах. До таких належить домінантно-естетичний підхід (що виявляється також в житті і філософіі) та принципово відмінне від європейського емоційно-інтонаційне середовище китайців. Останнє пов'язане зі смислорозрізнювальними принципами китайської мовної інтонації (на відміну від емоційно-психологічних європейських) з логічним звідси пріоритетом моторно-динамічного начала в фортепіанній грі, розумінням ліричного швидше як образотворчого, ніж виразного. Також переважаючими для китайського інтерпретатора $є$ несподівані яскраві контрасти (одна з ознак концертності) з рівністю динаміки кожного компонента образно-стилістичних комплексів, а не поступовість динамічних градацій крещендо і дімінуендо. Дійсно, основними компонентами концепту «щастя» в китайській традиційній культурі виступають п'ять земних благ: довголіття, багатство, здоров'я, чеснота, природна смерть - пов'язаних з минулим і майбутнім часом. Так відображаються ментальні уявлення етносу про досягнення гармонії між духовним і матеріальним і про сенс людського життя взагалі.

Таким чином, фортепіанна творчість Прокоф'єва гармонує з установками піаністичної школи Китаю віртуозною складністю як проявом високої Краси і виконавського тонусу, модусом радості (що відображає концертний модуль), інтонації (правда, з різними підставами) ліричного тонусу вираження.

Звернемося до порівняльної характеристики інтерпретацій Другого фортепіанного концерту Прокоф'єва китайською піаністкою Юйєю Ванг (на прізвисько «літаючі пальці», що кореспондує з «чарівними літаючими пальцями» самого Прокоф'єва) і деяких вітчизняних піаністів вищого ешелону. Для порівняльного аналізу обрані виконання Я. Зака (1959, Великий симфонічний оркестр Всесоюзного радіо і телебачення, диригент К. Зандерлінг), М. Петрова (1985, Державний академічний симфонічний оркестр, диригент Ю. Темірканов), В. Крайнєва (1981, оркестр Московської філармонії, ди- 
ригент Д. Китаєнко) і Юйї Ванг (2010, Люцернський симфонічний оркестр, диригент К. Аббадо). Другий концерт (1913-1923рр.) геть переполохав всю публіку, він включений С. Ріхтером до числа «трьох основних китів піанізму» (поряд з 29-ю сонатою Бетховена і Варіаціями Брамса), постійно виконувався Прокоф'євим у власних концертах і від початку 1930-х років міцно увійшов до репертуару більшості концертуючих піаністів. Концерт написаний напередодні Першої світової війни, з одного боку, і після раптового трагічного відходу з життя Максиміліана Шмідтгофа, з іншого, що, в тому числі, позначилося на характері твору.

Сьогодні цей твір визнано безперечним шедевром, він залишається одним з найскладніших для фортепіано і користується величезною популярністю серед китайських піаністів. Це перший великий, циклічний твір Прокоф’єва з відповідною зрілістю думки і масштабами фантазії, де він звертається до сфери національної архаїки в кращих традиціях російської класичної музики, але вже «в тій неповторній особистій манері, яка відрізняла Прокоф'єва з перших кроків на композиторському терені» $[4,79]$. До речі, концерт створювався одночасно зі «Скіфською сюїтою», привівши у захват Дягілєва саме завдяки «національному колориту, характеристичності і особливій пластичній виразності музичного матеріалу» (з подальшим балетним втіленням), і був обраний Прокоф'євим для першого авторського закордонного виступу. У Концерті явно домінує фортепіанний інструменталізм, який відображає як ситуацію пошуків нових звучань Прокоф'євакомпозитора, так і виконавські інтенції Прокоф'єва-піаніста - солюючий інструмент ніби навмисне заволодіває слухацькою увагою, «Перекриваючи» своєю значимістю і яскравістю оркестрові звучання, втілюючи ідею концертності. Таким чином, експресія цієї монументальної звукової фрески цілком відповідає повноті душевного світу молодої людини, не втрачаючи втім «істинної класичності мислення» $[4,78]$. Однак ігрові установки піанізму, фактурних пластів, динамічних контрастів та переважання скерцозно-моторного начала (що в якійсь мірі навіть нівелює контрастність частин циклу) підкреслюють якість концертності.

Характерна для композитора парадоксальність проявляється як на рівні форми (комбінація конструктивної чіткості і стихійної імпровізаційності), так і в мелодико-гармонічній мові (різноманітно-гострі гармонії в конструктивно простій мелодії, наприклад, Andantino I частини), різних входжень в національну специфіку («билинність» 
основної теми першої частини і другої теми четвертої - $\mathrm{i}$ «погляд на інший матеріал крізь призму національної архаїки» $[2,70])$.

Уже перша частина - це не сонатне алегро, хоча контраст двох тем і створює передумови для тричастинної структури. Стильовий зв'язок першої теми частини з протяжною ліричною пісенністю і дзвонністю створюють ефект історичної визначеності і просторової окресленості. Тема відразу широко позиціонується (у фортепіано та в оркестрі), але при цьому іiі виникнення і завершення реалізуються як «прояв в тиші»: чергування двох квінт T i S, а потім і звуків d-g на тлі витриманої тоніки в супроводі; повтор трихордової інтонації b-c-g в мелодії (трихорд виступає як узагальнений символ російського билинно-сказительського начала). Слов'янським знаком може служити і просторова характеристика теми - іiі підкреслена лінеарність, «рівнинність». Засобами втілення зазначеного простору виступають i «позбавлені емоцій» кварто-квінтові інтонації, ритмічна повторність і динамічна вирівняність, виразність лінеарного мелодійного руху. Так створюється ефект об'єктивування, часового і просторового дистанціювання об’єкта розповіді, певна філософічність, незмінність в своєму минулому часі.

Зазначені характеристики теми по-різному втілюються в інтерпретаціях піаністів з вибором того чи іншого образного спрямування. Так, Петров акцентує билинність теми, іï дзвонність як національні пріоритети - в деякому згладжуванні пунктирного ритму, «розлитій» широті дихання. Зак також схильний до підкреслення величавості теми, її дзвонності - підвищеною щільністю ведення звуку і звуковидобування, що надає його трактуванню певної романтичної забарвленості. В. Крайнєв при максимальному цілісному охопленні прокоф'євської мелодійної «лінії» виявляє незвичайну рельєфність фактури не тільки у функціональному співвідношенні ії голосів, але і в надзвичайно різноманітній артикуляційно-акцентуйованій вимові кожного з них. Складається відчуття, що піаніст грає не на монотембровому роялі, а на якомусь багатотембровому інструменті-оркестрі. Крайнєв також підкреслює-загострює пунктирність теми (пов'язану, в тому числі, 3 мовною інтонацією) і органічно застосовує агогічні прийоми, що створює неповторний, індивідуальний, живий «виконавський час» твору, що викликає асоціації з живою плинністю мови і власне часу. Ю. Ванг подає тему зовсім в іншому ключі: піаністка естетизує мелодію, немов милуючись і інтонацією, і фактурою, і їх виконавським інструментально-звуковим наповненням (вона «працює» зі 
звуком). Тонке естетство звучання, в той же час не позбавлене певної «плакатної» подачі як однозначності прагнення до Радості, впевненості в їі результуючій якості, що виражається в наповненості удару (вона прислухається до кожного тону), «красою» - виконавським тонусом, постійним слуховим контролем, особливим «пластичним ударом» (на відео помітна пластика руху рук, «неметушливість» пальців кисті). Явно домінує ігровий компонент - в естетизації всього акторсько-виконавського простору інструменталістки (форми руху рук і пальців, міміка, корпус з реакцією на фактурні, динамічні, штрихові прийоми). Ю. Ванг починає тему не на авторському р, а дещо яскравіше. Навпаки, у Крайнєва звучить прозоре, тонко психологізоване p, що надає більшої ефектності і рельєфності голосоведення і характерної проникливості образу.

«Слов'янська» дзвонність у китайської виконавиці носить естетично-образотворчий, барвистий характер на відміну від слов'янських традицій епічної дзвонності у Петрова і Зака в характерній подачі акордових комплексів, заворожуюче-сугестивної, декоративно-казкової дзвонності на мікроостинатному повторі. В подальшому розвитку Концерту дзвонності розширює свій формат до «скомороших», «блазнівських» дзвонів в другій темі і в каденції I частини, дзвоново-тремолююче звучання в II частини - «Скерцо», сфера «символістської» дзвонності доповнюється в двох з'єднувальних епізодах IV частини (витримані тихі акорди, які створюють статичний ефект занурення-вслуховування). Описаній відстороненій дзвонярській сфері протистоїть, на думку Калашникової, «скіфське» начало «стихійної» дзвонності, «яка сконцентрована в крайніх частинах концерту і створює полюс, протилежний епічній відстороненості (першої теми першої частини)... Такі дзвінкі звучання належать сфері авторської рефлексії, екстатизму, апокаліптичних настроїв, які, здавалося б, більш характерні для стилю С. Рахманінова та О. Скрябіна, ніж Прокоф'єва... Таке суб'єктивно-особистісне прочитання дзвону виявилося особливо затребуваним на початку XX століття з його «завихреною» емоційно-психологічною атмосферою» [2, 75]. Тут ключовою для прокоф'євського стилю з характерною інтонаційноритмічною сугестією виступає переважно ритмічна (а не мелодійна) структура дзвонів. Відповідно в інтерпретаціях Н. Петрова і Я. Зака ця рефлексивність дзвонності підкреслюється, стає важливим драматургічним знаком. У грі Ю. Ванг - трансформується в наднаціональну естетизовану красивість. У В. Крайнєва відсторонюється дзвонова 
педальність-гул на користь європеїзованої добротності фактурної і артикуляційно-тембральної рельєфності.

Друга тема першої частини, контрастна щодо першої теми загостреністю інтонацій і гармоній, граціозністю, але й споріднена одночасно. Ювелірність барвистих поворотів ії пасажів, що називається, не дає піаністу і слухачеві нудьгувати. У Петрова вона подається 3 розмахом і навіть деякою масштабністю, «розгойдуванням» простору. Зак згладжує як акцентуацію, так і артикуляційно-динамічні показники виконання. Ванг презентує тут блискучу гру, абсолютно не рефлексує, продовжуючи насолоджуватися «потоком життя». Крайнєв демонструє найтонші ігрові та навіть психологічні межі прокоф'євського образу, наближається, на наш погляд, до авторської інтерпретації.

Наступна за експозицією каденція фортепіано, яку Дягілєв назвав «дикою твариною» $[2,77]$, фактично замінює розробку і стає кульмінацією першої частини Концерту: вихори призвуків дзвону, гранично далекі регістри, деяка стихійність і хаотичність звучання втілюють прокоф'євську фортепіанну експансію - рояль не просто гідна конкуренція оркестру, але скоріше - переможець його (тут концертну ознаку соло можна вважати однозначною).

Композиторська фантазія у винаході нових фортепіанних фактурних і аплікатурних комплексів (аплікатуру до цього концерту Прокоф'єв виставив) воістину невичерпна - Прокоф’єв-піаніст і Прокоф'єв-композитор нагадують протистояння рояля і оркестру. Петров і Зак знову підкреслюють дзвонову якість, Зак також загострює іiї в пунктирному ритмі з ударним фортепіанним туше. Ванг спочатку привносить до фортепіанного соло «світлі» звучності, що не заважає їй все ж досягти драматичного напруження до кінця зі специфічною ментальною якістю Краси як мети і як шляху (віртуозна доблесть в досягненні Краси), виконавиця при цьому здійснює подвиг (в тому числі віртуозності), але без жертовності, триває гра Красою, 3 Красою, з інструментом, з оркестром, з фортепіанно-фактурними елементами високої складності. Крайнєв, досягаючи надзвичайної цілісності й тонкого драматизму (що робить каденцію дійсної «розробкою» і кульмінацією всієї частини), підносить слухачеві рояль «у всій красі» інструментально-звукових, темброво-артикуляційних, просторово-фортепіанних артистичних прийомів, повністю підлеглих художній ідеї, симфонізму їх інструментальної подачі і концептуального мислення. Рояль стає справжнім оркестром і в різно- 
манітності фактурних ліній. Особлива роль відводиться виконавській темпоральності в створенні цілісності, виконавського тонусу подачі структур і звуку, абсолютної органічності поєднання і переходів різноманітних ритмічних структурних одиниць в їх спрямованості до мети. Після всього цього з особливим почуттям сприймається повернення до початкової билини першої теми.

Друга частина Концерту - Скерцо - знову демонструє первинність короля-рояля: його блискучі пасажі явно панують над оркестром. Солістові тут доводиться непросто - виконання частини не повинно перетворитися на «етюд», уникнути останнього допоможе ювелірно вивірена артикуляція. Але і відповідна нагорода очікує піаніста, найяскравіша віртуозність партії фортепіано не може не бути оцінена по достоїнству публікою (звичайно, в разі зазначеної артикуляційної майстерності). В цьому плані явно лідирує Крайнєв, його артикуляція в будь-якому темпі і динаміці (а тут ця гра динамікою важлива) - бездоганна, що вигідно презентує як виконавця, так і інструмент, а також відтіняє смислову гру структурних одиниць форми.

Третя частина Концерту - Intermezzo - демонструє характерні прокоф'євські звукообрази в дусі «химерних і пишно-примхливих архітектурних форм фантазії бароко», за твердженням Б. Асаф'єва (цит. за: [4, с. 81]). Тут вже активно працює й оркестр. Вступна оркестрова тема яскраво характерна, іiі могутньо-великоваговий, «до землі» хід створює суворий образ: остинатні фігури, ритмічні й інтонаційні, немов рухаються на одному місці або вниз. Низькі струнні, фаготи і туби супроводжуються «ухаючими» ударами великого барабана і литавр. Майже по-звірячому ревуть тромбони (втім в оркестрі Д. Китаєнка звучання тромбонів більш облагороджене, можливо це пов'язано з найтоншими піаністичними і смисловими знахідками Крайнєва). Похмурий гротеск в інтерпретації Петрова (дещо згладжений, але присутній і у Зака) немов відображає атмосферу воєнних катаклізмів першої половини XX століття (як в «Скіфській сюїті» Прокоф’єва, і створених значно пізніше, в 1940 році, «Симфонічних танцях» С. Рахманінова). У Крайнєва і особливо у Ванг «страшні» ваговитість і зловісність поступаються місцем ігровій стихії - ювелірно-химерній гротесковій у першого і танцювально-кокетливій, дещо мрійливій у другої. У виконанні Крайнєва вражає «неземна» (інакша) кантилена (цифра 61), що служить контрастним компонентом єдиного моторно-ліричного цілого музики Прокоф'єва. У китайської піаністки цей епізод набуває вигляду казкової красивої фантастики 
з особливим ставленням до звуку. В певному «божевіллі» фактури $є$ зворотна сторона (єдиного цілого) - середній епізод частини носить таємничо-привабливий характер: його заворожуюча барвистість, чарівна грація пластики легких ковзаючих мотивів не залишають сумнівів в існуванні (нехай і далеко) істинної (або умовної) казки.

Стрімкий фінал Концерту з підкреслено ритмічним компонентом і стрибкоподібною (майже пуантилістичною) інтонацією має свою середину зі спокійною широкою мелодією на натуральному мінорі, без ритмічних вибухів. Серед завихрень крайніх розділів частини ця, одна з кращих, прокоф'євська мелодія - за впливом сильніше «грому серед ясного неба». Трактування Петрова відрізняється певною зловісністю, навіть трагізмом, середина дещо спрощена у вимові і характері. Зак також додає зловісну гротескність, середній розділ уподібнює народній пісні, згладжуючи прокоф'євські інтонаційні та артикуляційні тонкощі. Ванг радіє вихровій спрямованості прокоф'євської мелодики і власних «літаючих пальців», середній розділ камернізується і набирає рис розповідності. Крайнєв своїми блискучими ювелірними акцентуацією і артикуляцією, грою гучності надає середній частині балетного характеру (що повністю відповідає композиторському трактуванню) і прекрасно відтіняє крайні розділи частини. Темпоральні показники піаніста, як завжди - на висоті, що допомагає досягти потрібного виконавського тонусу, надзвичайної цілісності у виконанні всього циклу і концептуалізує жанр.

Цікавим видається порівняння темпоральних показників обраних для аналізу інтерпретацій, адже тонка грань прокоф'євської хронотопічної організації музичних образів є одним з провідних показників його стилю. В цілому найшвидшою виявляеться китайська піаністка, темповий показник відображає ії концепцію радісної спрямованості і фантастично-казкової споглядальності «земного» (поточного) спрямування, що відображене технічно, перш за все у віртуозному показнику (який, втім, у неї не є самоціллю - звук піаністки цілком «наповнений» здоровим глуздом і відрізняється «чоловічою» щільністю і матеріалізованою тембральністю). Навпаки, Петров - найбільш «повільний», що відповідає його націленості на билинність, величність першої частини; традиційну скерцозність другої (тут він майже не відрізняється від колег); майже на дві хвилини «відстає» в «зловісній» у нього третій частині і в цілому в швидкому темпі формує трагічну концепцію фіналу. Зак займає дещо середнє становище 
в обраних трактуваннях, але несподівано швидше подає зловіснотрагічний фінал. Крайнєв, дещо «заспокоюючи» першу, «билинну» частину, філософізуючи ії̈ певним чином; технічний-характерний в другій (при його ювелірній артикуляції); не «відтягує» третю, наділяючи ювелірною точністю кожен тон блискуче артикульованих пасажів і тем; фінальний «балетний» тонус просторово помітний і тому не «поспішає» в часі. Крайнєв відрізняється також, на наш погляд, найбільшою цілісністю хронотопічної організації і концептуалізовано-психологізованої образної сфери. Симфонізм подачі матеріалу концерту відрізняє Зака і Плетньова. Ванг і Крайнєв органічно поєднують цей показник з камерно-витонченою стороною. Гра ж виступає домінантною ознакою концертності у всіх виконавців, правда з різними стилістичними спрямуваннями.

Висновки. Гротесково-скомороші образи в непростому замісі Концерту зі специфічною прокоф'євською лірикою і билинною епікою, дзвонною ритуалікою (або Красою) створюють психологічно складну систему взаємоперетворених образів, що індивідуально розуміється різними інтерпретаторами. Архаїчне минуле і сьогодення, казка-вигадка і те, що відбувається на наших очах, витонченість лірики з гротескною ламкою-спотворенням - все існує в єдиному ігровому часіпросторі, як в єдиній цілісній людині, завдання якої обрати потрібне, правильне, істинне. Завдяки емоційній яскравості, високого рівня патетиці, епічному розмаху Другий фортепіанний концерт виявляє зв’язок з російською романтичною фортепіанною школою (А. Єсіпова та ін). Одночасно нестримна сила молодості композитора сприяла тій мірі новизни (що, власне, дозволяє жанр інструментального концерту), яка викликала масу суперечливих, але в рівній мірі бурхливих відгуків.

Зазначені характеристики виконавських інтерпретацій фортепіанних концертів Прокоф'єва свідчать про провідні риси концертності як визначаючої їх стильовий зміст у єдності діалогічного (полілогічного) характеру, театралізовано-ігрових інтенцій, віртуозно-актуалізованих специфічних темброво-артикуляційних властивостей фортепіанного звучання та естетичного концепту Радості. А урізноманітнена індивідуалізована виконавська творчість спроможна отримувати відчутний резонанс при взаємодії з установками національних піаністичних шкіл. 


\title{
СПИСОК ЛІТЕРАТУРИ
}

1. Асафьев Б. Книга о Стравинском. М.: Тритон, 1929. 404 с.

2. Калашникова А. В. С. Прокофьев и скифские мотивы в культуре Серебряного века: дис. ... канд.. искусств.: 17.00.02 / Нижегородская гос. консерватория (академия) имени М. И. Глинки. Нижний Новгород, 2008. 204 с.

3. Кравец Н. Фортепианные концерты Прокофьева: дис. ... канд искусств.: 17.00.02 / Гос. ин-т искусствознания. М., 1999. 169 с.

4. Мартынов И. Сергей Прокофьев: жизнь и творчество. М.: Музыка, 1974. $560 \mathrm{c}$.

5. Сюй Бо. Феномен фортепианного исполнительства в Китае на рубеже XX-XXI вв.: дис. ... канд. искусств. Ростов-на Дону, 2011. 149 с.

\section{REFERENCES}

1. Asafiev, B. (1929). The book is about Stravinsky. M.: Triton [in Russian].

2. Kalashnikova, A. V. S. (2008). Prokofiev and Scythian motifs in the culture of the Silver Age. Candidate's thesis. Nizhny Novgorod: The Nizhny Novgorod State University. conservatory (academy) named after M. I. Glinka [in Russian].

3. Kravets, N. (1999). Piano concerts of Prokofiev. Doctor's thesis. Moscow / Gos. Institute of Art Studies [in Russian].

4. Martynov, I. (1974). Sergei Prokofiev: life and work. Moscow: Music [in Russian].

5. Xu, Bo (2011). Phenomenon of piano performance in China at the turn of the twentieth and twenty-first centuries. Rostov-on-Don / Rostov State Conservatory. S. V. Rachmaninov [in Russian].

Стаття надійщла до редакції 14.06.2017

УДК 78.03/781.1+786.2/78.071.2

\author{
Гань Сяосюе \\ https://orcid.org/0000-0003-4501-1312 \\ здобувач кафедри історії музики \\ та музичної етнографії \\ ОНМА ім. А. В. Нежданової \\ OdGanXiaoxue@gmail.com
}

\section{КОМПОЗИЦІЙНІ ТА ТЕКСТОЛОГІЧНІ ФУНКЦІЇ ПРИЙОМУ ВІДЧУЖЕННЯ В МУЗИЦІ}

Мета статті - розкрити значення та стилістичне походження прийому відчуження в музиці. Методологія дослідження забезпечується синтезом естетико-семантичного та текстологічного підходів. $\mathbf{H a -}$ укова новизна полягає у новому визначенні природи та механізму дії при-

(C) Гань Сяосюе, 2017 